\title{
Pupils Perception of Using YouTube and Autonomous Learning
}

\author{
Sakina Bibi Mohd Shariff ${ }^{1}$, Parilah Mohd Shah ${ }^{2 *}$ \\ ${ }^{1}$ SMK Sultan Tajul Ariffin Manong, Perak, Malaysia \\ ${ }^{2}$ Faculty of Education, Universiti Kebangsaan Malaysia, Bangi, Malaysia \\ Email: ${ }^{\star d r p a r i l a @ g m a i l . c o m ~}$
}

How to cite this paper: Shariff, S. B. M., \& Shah, P. M. (2019). Pupils Perception of Using YouTube and Autonomous Learning. Creative Education, 10, 3509-3520. https://doi.org/10.4236/ce.2019.1013270

Received: November 4, 2019

Accepted: December 28, 2019

Published: December 31, 2019

Copyright (c) 2019 by author(s) and Scientific Research Publishing Inc. This work is licensed under the Creative Commons Attribution International License (CC BY 4.0).

http://creativecommons.org/licenses/by/4.0/

\begin{abstract}
The purpose of this study is to examine pupils' perceptions of using YouTube and autonomous learning. The population consisted of pupils of form one till form two of SMK Sultan Tajul Ariffin Manong, Perak, Malaysia. The design of the study was done using a survey methodology. A survey using questionnaires was conducted among these students to gauge their perceptions towards the use of YouTube in their learning of English and autonomous learning. SPSS was used for the statistical analyses. The primary aim is to examine pupils' perceptions in using YouTube videos to enhance their learning and autonomous learning. The respondents of this study were 50 pupils ranging from form one till form two pupils in the same school. Data were gathered using questionnaires to identify pupils perceptions of using YouTube and autonomous learning. This study analyzed the data descriptively, using percent and frequency in the procedure of data analysis. Through SPSS, the findings showed that there was a significant difference in the perception of the pupils using YouTube towards their belief in the usage of the application and autonomous learning. The study shows that the YouTube application is highly accepted among these pupils. The experiences they gained were also worthwhile to be acknowledged as a way of self-learning.
\end{abstract}

\section{Keywords}

Pupils Perception, YouTube, Autonomous Learning

\section{Introduction}

Many leading researchers have found that technology has its power in upgrading pupils understanding. Paulsen, for example, stressed in 2001 that the use of Internet materials would be useful to students. Benson (2011) said online learning 
helps to provide rich linguistic and non-linguistic understanding to learners.

Berk (2009) showed that the use of videos in educational settings has positive effects on both brain and emotional senses hemispheres of the students. This has an impact on students showing their connectivity of thoughts well by watching videos and increasing the pupils' memory. After all, by watching videos, students remember more than just reading in the text form.

Wang (2005) indicated that learners can link the language ideas to their experience by incorporating technology into the classroom. Additionally, today's use of technology is strongly linked to the Internet. Sipalan (2013) revealed that $13.4 \%$ or more than 3.9 million Malaysians were "electronic natives", accounting for approximately three-quarters of the country's young people who regarded their computer or electronic skills.

Paulsen (2001) said that when online materials are used effectively, learners will receive good benefits. Benson (2011) indicated that online learning presents fresh language through a broad spectrum of media and offers different decisions, thus providing the learners with a wealthy linguistic and non-linguistic input. YouTube's application with a wide range of videos helps in viewing, downloading and uploading videos and sharing videos as well. In this application, pupils can also demonstrate their likes and comments.

Yunus M, et al. (2010) said there is a need to study the perception of users towards ICT to maximize its usage. Furthermore, Yunus M, et al. (2019) have even very recently recommended online learning till tertiary level. Thus, Malaysian students should at an early age be equipped with the technology. Balcikanli (2011) found that students took advantage of YouTube in enhancing their language proficiency and independence skills and cultural competence.

Pupils face a lack of time in English learning classes in schools. They need to be able to have more of their time on their own to go deeper into learning the English language. Spending their time online going through YouTube is a way they could enhance their learning of the language. Using online materials on YouTube which are catchy and attractive give good motivation for them to learn the English language. Motivation and attitude are the two elements which are fundamental in learning a second language as well as to provide the continuity needed to carry on the learning process (Mohd Shah \& Abdullah, 2014).

The significance of this research will be seen where teaching the English Language in secondary schools will create a fun learning environment to it. It also stimulates an autonomous learning on part of the pupils. These will bring good progress in the standard of competency among the learners. For the teachers it would create a dynamic approach in their classes.

Two research questions

1) What is the perception of form One and Form Two pupils of SMK Sultan Tajul Ariffin on using YouTube?

2) What are the experiences that these pupils have in using YouTube? 


\section{Literature Review}

The goals of the operations and the approach Technology used on the internet, which has a great impact on teaching and learning English in schools. So, it was well-known fact that Malaysia's Ministry of Education's Secretary-General, Dr. Johari bin Mat, observed the importance of technology in the country's educational education and teaching scheme in 2000 . He added that the system wants to be adapted to meet the evolution of technology concerning content, exercise and mastering material delivery. This is cited by Nawawi, M. H., Asmuni, A., \& Romiszowski, A. (2003).

To add to this, Schmenk observed in 2005 that the importance of computer systems and the increasing popularity of computer technology in the language teaching settings have somehow fostered a fresh level of learner autonomy. Technology-enhanced language learning (TELL) reflected a growing and evolving interest in foreign language training, and the acquisition of second language (Oxford, 2004).

In a research conducted by Sanoui and Lapkin (1992), the significance of technology assistance in creating features of autonomous knowledge gain among French high school pupils was brought about. Here we can see ICT technology gives a great helping hand in the learning of a language. In 1996, Warschauer found that three common variables affected learners in the technology-based classroom were recognized as communication, empowerment, and learning.

Empowerment introduced the sense of security when the students in college felt much less alienated and were much less afraid of contacting others when they were engaged in learning through technological environment. Learning was the rest of the elements. According to the students' answers, they thought they had control over their mastering by using computer because of the reality that they were able to study faster and more independently.

\section{Theoretical Framework.}

Two models which focused on technology and learner autonomy were used in this study (Figure 1).

External variables include influences from teachers, their social background and themselves receive in using YouTube in their independent language learning. Perceived usefulness $(\mathrm{U})$ is the pupils' belief that their performance will

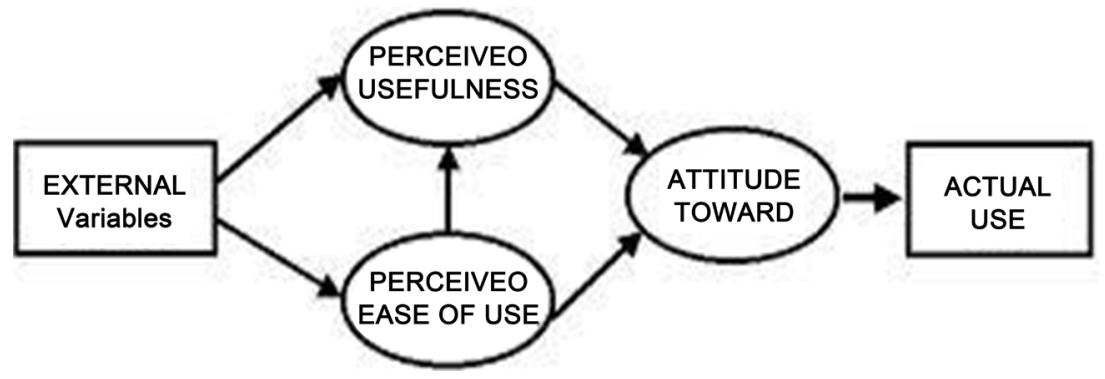

Figure 1. Technology acceptance model (Davis, Bagozzi, \& Warshaw, 1989). 


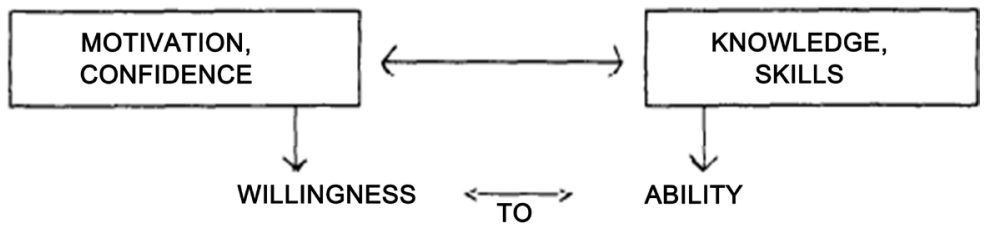

MAKE AND CARRY OUT CHOICES

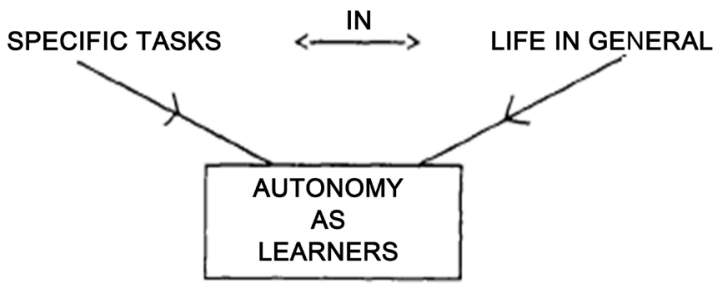

Figure 2. Components and domains in language learning (Littlewood, 1996).

increase by using You Tube application. Perceived ease of use (EOU) refers to "the degree to which the user expects the target system to be free of effort" (Davis, Bagozzi, \& Warshaw, 1989). In this context, EOU refers to students' perception about the degree of effort needed to use YouTube in independent language learning (Figure 2).

The concept of autonomy focuses on self in awareness (self-aware) and decision-making skills (independent decisions), and emphasizes on freedom in learning which are ability and willingness to make choices, and related to task in developing autonomy. Autonomy as a learner is able to do work independently and uses suitable learning strategies inside and outside the classroom.

\section{Methodology}

This research used a questionnaire which was once relevantly tailored from other related questionnaires from the past researches. The questionnaires are compiled in a way that ought to probe the students' appreciation and their learning autonomy. The questionnaires have been set up in twin languages that are English and the Malay language.

The samples responded to the items and statements in the questionnaire which were shown mostly in the form of Likert scale. The data collected and was analyzed using SPSS. This is in compliance with Babbie (2010), "quantitative design focuses on gathering numerical data and generalizing it across groups of people" and also Quantitative Research Method (QRM) (Farhady, 2013).

\subsection{Research Sample}

The population sample for this research SMK Sultan Tajul Ariffin Manong, Perak. It is a secondary school with a majority of Malay pupils. It caters for the population around the area and it is the only secondary school there. It is about $25 \mathrm{~km}$ from Bandar DiRaja Kuala Kangsar and on the north $18 \mathrm{~km}$ from Bruas the next nearest town on the south. 50 respondents were chosen randomly to take part in this survey. 


\begin{tabular}{|c|c|c|c|c|c|}
\hline & & \multicolumn{4}{|c|}{ Age ranges of the pupils } \\
\hline & & Frequency & Percent & $\begin{array}{l}\text { Valid } \\
\text { Percent }\end{array}$ & $\begin{array}{c}\text { Cumulative } \\
\text { Percent }\end{array}$ \\
\hline Valid & $\begin{array}{l}12-13 \\
\text { years }\end{array}$ & 18 & 36.0 & 36.0 & 36.0 \\
\hline & $\begin{array}{l}14-15 \\
\text { years }\end{array}$ & 32 & 64.0 & 64.0 & 100.0 \\
\hline & Total & 50 & 100.0 & 100.0 & \\
\hline
\end{tabular}

\subsection{Research Instrument}

There are 16 questions in total that have been divided into two parts; Part 1 and Part 2.

Part 1 consists of 9 questions that ought to discover students' perception of using YouTube in their learning of the English language.

Part 2 was to investigate the experiences the pupils had in their usage of videos on YouTube.

Each item in the questionnaire was developed for the purpose of achieving the objectives of the research. The questionnaire consisted of three sections; A, B, and $\mathrm{C}$. The first section elicited the respondents' demographic background which involved age, gender, race and UPSR band (English band at the primary school level).

Seven statements in Section B were adapted from a questionnaire developed by Afari-Kumah and Achampong (2010) for their study entitled "Modeling Computer Usage Intentions of Tertiary Students in a Developing Country through the Technology Acceptance Model". In this section, the items were designed to achieve the first research objective which is to investigate students' perception in using YouTube videos to learn English independently. Another two questions were constructed based on the 15 categories of videos featured on YouTube identified by Ghasemi, Hashemi, and Bardine (2011).

Meanwhile, items in Section C were used to accomplish the second objective of this research which was to study what were the pupils' experiences in using YouTube videos in enhancing their learner autonomy. The respondents were asked whether they enjoy choosing materials on YouTube for their language learning. They were also required to state whether finding materials on YouTube was easy or not.

A total of fifty questionnaires were administered and distributed to the respondents and all of them were completely answered and returned.

\section{Findings}

The findings will be discussed according to Research Questions.

\section{Research Question One}

Approximately 72 percent of participants either agreed or agreed heavily that using YouTube videos in their own moment would give them higher control over their research. This could be recognized as agreeing that YouTube made them aware of learning on their own moment as well as making them connected 
to their learning without interruptions of a greater authority level. They weren't produced to do it by someone, but they were able to do it on their own.

Question 1. Using YouTube videos in my own learning time gives me greater control over my studies.

\begin{tabular}{llcccc}
\hline & Frequency & Percent & Valid Percent & Cumulative Percent \\
\hline Valid & STRONGLY DISAGREE & 1 & 2.0 & 2.0 & 2.0 \\
DISAGREE & 13 & 26.0 & 26.0 & 28.0 \\
AGREE & 27 & 54.0 & 54.0 & 82.0 \\
STRONGLY AGREE & 9 & 18.0 & 18.0 & 100.0 \\
Total & 50 & 100.0 & 100.0 & \\
\hline
\end{tabular}

Question 2. Using YouTube videos in my own learning time improves my learning productivity.

\begin{tabular}{llcccc}
\hline & Frequency & Percent & Valid Percent & Cumulative Percent \\
\hline Valid & STRONGLY DISAGREE & 5 & 10.0 & 10.0 & 10.0 \\
& DISAGREE & 10 & 20.0 & 20.0 & 30.0 \\
AGREE & 28 & 56.0 & 56.0 & 86.0 \\
STRONGLY AGREE & 7 & 14.0 & 14.0 & 100.0 \\
Total & 50 & 100.0 & 100.0 & \\
\hline
\end{tabular}

Approximately 70 percent of participants agreed that using YouTube videos on their own time has improved the productivity of their learning. This demonstrates that the time spent on following YouTube videos on their own made them have a stronger level of teaching productivity. This was heavily agreed by 20 percent of them, while 50 percent also agreed.

Attitude towards the Use of YouTube Videos in English Language Learning

Q3 I have easy access to YouTube website

Q4 I am confident in using YouTube to learn English

\begin{tabular}{lccc}
\hline & \multicolumn{2}{c}{ Responses } & \\
\cline { 2 - 3 } & N & Percent & \\
\hline DISAGREE & 28 & $28.0 \%$ & $56.0 \%$ \\
AGREE & 53 & $53.0 \%$ & $106.0 \%$ \\
STRONGLY AGRE & 19 & $19.0 \%$ & $38.0 \%$ \\
Total & 100 & $100.0 \%$ & $200.0 \%$ \\
\hline
\end{tabular}

53.0 percent agreed with this in answering user-friendly questions such as simple access to the YouTube website and confidence in using YouTube to learn English, while 19.0 percent agreed heavily. This shows that 72 percent of participants are optimistic about using YouTube videos because they have simple access and are confident that they will use the apps. 


\section{Research question Two}

Q1. Enjoy choosing materials on YouTube in learning English.

\begin{tabular}{llcccc}
\hline & & Frequency & Percent & Valid Percent & Cumulative Percent \\
\hline Valid & DISAGREE & 14 & 28.0 & 28.0 & 28.0 \\
& AGREE & 30 & 60.0 & 60.0 & 88.0 \\
STRONGLY AGREE & 6 & 12.0 & 12.0 & 100.0 \\
Total & 50 & 100.0 & 100.0 & \\
\hline
\end{tabular}

For question 1 which values their enjoyment in choosing videos on YouTube, a total of $72 \%$ of the pupils agree with the statement while $12 \%$ seem to agree strongly. This tells that majority of the pupils enjoy in choosing videos on YouTube. This could be in relevance with the idea that there are a variety of choices available which the pupils can browse and attach enjoyment to it.

Q2. I feel more comfortable in using YouTube to learn English independently.

\begin{tabular}{llcccc}
\hline & Frequency & Percent & Valid Percent & Cumulative Percent \\
\hline Valid & STRONGLY DISAGREE & 1 & 2.0 & 2.0 & 2.0 \\
& DISAGREE & 12 & 24.0 & 24.0 & 26.0 \\
AGREE & 33 & 66.0 & 66.0 & 92.0 \\
STRONGLY AGREE & 4 & 8.0 & 8.0 & 100.0 \\
Total & 50 & 100.0 & 100.0 & \\
\hline
\end{tabular}

In answering Question 2 which shows whether the pupils are comfortable in using YouTube to learn independently, 74\% of the pupils agree with it being comfortable for them in using YouTube independently while 8\% strongly agreed to it. On the other hand only $2 \%$ strongly disagreed to the statement. This shows the pupils are comfortable with it.

Q3. Using YouTube in independent language learning gives me control on how long to spend on each video.

\begin{tabular}{llcccc}
\hline & Frequency & Percent & Valid Percent & Cumulative Percent \\
\hline Valid & STRONGLY DISAGREE & 1 & 2.0 & 2.0 & 2.0 \\
& DISAGREE & 14 & 28.0 & 28.0 & 30.0 \\
AGREE & 34 & 68.0 & 68.0 & 98.0 \\
STRONGLY AGREE & 1 & 2.0 & 2.0 & 100.0 \\
Total & 50 & 100.0 & 100.0 & \\
\hline
\end{tabular}

In statement 3 where the pupils are questioned on their freedom of choice and control, $70 \%$ agree with it. The pupils agree that they are having freedom to choose and control their learning through using YouTube videos. Meanwhile those who disagree consist of $30 \%$ this could be due to their ages at 12 to 14 years 
they may prefer to have instructors. However this is only for $30 \%$ of the cases.

Q4. I enjoy learning using YouTube.

\begin{tabular}{|c|c|c|c|c|c|}
\hline & & Frequency & Percent & Valid Percent & Cumulative Percent \\
\hline \multirow[t]{5}{*}{ Valid } & STRONGLY DISAGREE & 2 & 4.0 & 4.0 & 4.0 \\
\hline & DISAGREE & 11 & 22.0 & 22.0 & 26.0 \\
\hline & AGREE & 30 & 60.0 & 60.0 & 86.0 \\
\hline & STRONGLY AGREE & 7 & 14.0 & 14.0 & 100.0 \\
\hline & Total & 50 & 100.0 & 100.0 & \\
\hline
\end{tabular}

For question 4 on testing the pupils' enjoyment on learning independently, $74 \%$ seem to agree with this and $14 \%$ seem to strongly agree with it. Meanwhile only $4 \%$ were strongly disagreeing with the statement.

Q5. Using YouTube videos independently makes language learning more difficult.

\begin{tabular}{llcccc}
\hline & Frequency & Percent & Valid Percent & Cumulative Percent \\
\hline Valid & STRONGLY DISAGREE & 14 & 28.0 & 28.0 & 28.0 \\
& DISAGREE & 25 & 50.0 & 50.0 & 78.0 \\
AGREE & 11 & 22.0 & 22.0 & 100.0 \\
Total & 50 & 100.0 & 100.0 & \\
\hline
\end{tabular}

For question 5 in testing the pupils' responses to whether using YouTube videos were making their learning more difficult, $78 \%$ of the pupils seem to disagree with it and $28 \%$ said they strongly disagreed. This showed the pupils were finding YouTube videos were actually making their learning easier to be comprehended.

Q6. I watch the same videos on YouTube more than once to gain better understanding of the videos.

\begin{tabular}{lcccc}
\hline & Frequency & Percent & Valid Percent & Cumulative Percent \\
\hline STRONGLY DISAGREE & 1 & 2.0 & 2.0 & 2.0 \\
DISAGREE & 12 & 24.0 & 24.0 & 26.0 \\
AGREE & 23 & 46.0 & 46.0 & 72.0 \\
STRONGLY AGREE & 14 & 28.0 & 28.0 & 100.0 \\
Total & 50 & 100.0 & 100.0 & \\
\hline
\end{tabular}

For question 6 that asks pupils whether they watched You Tube videos repeatedly in order to gain better understanding, $74 \%$ of the pupils agreed to it. This also will explain their strategies in learning through YouTube videos.

\section{Conclusion and Recommendation}

\section{Research Question One}

When discussing the pupils' perception about using YouTube in their learning 
the results were implicitly telling that the pupils actually enjoy using YouTube. The reasons that they were actually involved in their learning were due to the easy access to the application and readily available to them.

The pupils felt the application has created a comfortable environment for them to learn at their own pace. This showed it has positively affected their learning. When they have control of their studies, this could be assumed that they were learning without any distraction. This is a great move since the pupils are of 12 - 14 years of age and just completed their primary school level of education. Soon they will be entering a higher level of education. Beginning at their age now is considered most suitable for them to be learning on their own.

\section{Research Question Two}

When the pupils related to their experiences in using the application YouTube they seem to have considered it as a tool that helped them manage and at the same time gave them control and freedom of their choice in enhancing their learning outcome. They do not consider it as being a difficult and time wasting but a constructible way of learning.

This helped them because they have enjoyed the atmosphere of learning created by the application and have shown improvement in their apt for the language. This was found in question one when the pupils were asked of the control they had over the learning through YouTube application. This showed the application made them work in the way they were satisfied and led to the improvement in their language skills.

The experiences they had in using the application was considered to be great and made them learn on their own. This means that the pupils were gauging on their own competence to come to the level that they were able to complete the tasks in their own learning. The pupils too felt that learning using YouTube application did not create difficulty for them but on the other hand made them more advanced in their learning environment. This could be they gain momentum in their learning strategy by using YouTube as said by Alimemaj (2010).

The findings of this research give the students an idea to develop teaching and learning resources for the teachers and lecturers. The findings here indicate that learners used YouTube and the application was helpful in English language learning. Therefore, this should be considered a development that can be used by educators and lecturers in language teaching and learning.

Hashim et al. (2018) found through a study of polytechnic students that had more positive perception of mobile technology. This creates a good influence on their learning atmosphere. In addition Hashim \& Isa (2012) studied the anxiety level among students in speaking English. Further work by Sharif et al. (2018) where an interactive learning using YouTube could foster confidence among ESL students in fun learning environment. This would break off the barrier of nervousness and anxiety faced by pupils because it brings more freedom and does not bore the pupils. 
The pupils become more matured and their teachers are less stressed. Using YouTube videos on their own, students know the phase that can assist them in their endeavors. They will therefore feel more comfortable and driven to know the language on their own with the assistance of Videos on the YouTube. Furthermore as the nature of videos provided comprised. Some videos on YouTube provide music and songs that enhance the vocabulary of the pupils. This has positive effects as said by Abidin $Z$ et al. (2011). This study also provides pupils with awareness of using YouTube videos in language learning. Furthermore Muniandy and Veloo (2011) videos brought great visual stimulus by providing text, sounds and graphics.

This can also encourage and engage students outside the classroom to learn English separately. In the meantime, ESL learners are also advised to use YouTube videos as one of the instruments in the autonomous teaching. Berk (2009) considered YouTube videos in an educational manner are beneficial for 'illustrating a concept, presenting an alternative viewpoint, stimulating a learning activity, and motivating the students.

Mohd and Maat (2013) came to findings that students referred to YouTube as a learning material in enhancing their understanding. Therefore, improving their language learning, such as vocabulary enhancement and correct pronunciation, is of utmost importance for students. Students need more experience and time in the classroom to learn the language. The advancement of the pupils in language learning may be restricted by limited time and practice in the classroom. This can be replaced by autonomous learning done by the pupils in their own time.

Anyarge and Anyarge (2009) indicated that in cognitive processing and memory, videos are the most helpful instruments. In addition, they also stated that after an hour of observing it, students can remember $80 \%$ of the video content compared to the content of a lecture in which they can only recall $25 \%$. It is therefore suggested that educators and lecturers see this approach seriously as to create autonomous learning for their pupils.

\section{Implications}

This study has brought a very positive impact on students using YouTube to gain knowledge since they had positive experiences. The number of pupils was only 50 of them and most had computers at home. It is advised in further research to also include resources provided at school level such as computer rooms, resource centres in school since this can enhance autonomous learning. Yeaboah (2015) had emphasized the aspect of having enough equipment and resources in providing ICT learning.

\section{Conflicts of Interest}

The authors declare no conflicts of interest regarding the publication of this paper. 


\section{References}

Abidin, Z., Jafre, M., Pour-Mohammadi, M., Singh, B., Kaur, K., Azman, R., \& Souriyavongsa, T. (2011). The Effectiveness of Using Songs in YouTube to Improve Vocabulary Competence among Upper Secondary School Studies. Theory \& Practice in Language Studies, 1, 1488-1496. https://doi.org/10.4304/tpls.1.11.1488-1496

Afari, E., \& Achampong, A. (2010). Modeling Computer Usage Intentions of Tertiary Students in a Developing Country through the Technology Acceptance Model. International Journal of Education and Development Using ICT, 6, 102-116.

Alimemaj, Z. (2010). YouTube, Language Learning and Teaching Techniques. The Magazine of Global English Speaking Higher Education, 2, 10-12.

Anyagre, P., \& Anyagre, S. (2009). The Use of Video and Multimedia in Teacher Education.

Babbie, E. R. (2010). The Practice of Social Research. Belmont, CA: Wadsworth Cengage.

Balcikanli, C. (2011). Long Live, YouTube: L2 Stories about YouTube in Language Learning. In Annals of Language and Learning: Proceedings of the 2009 International Online Language Conference (p. 91). Irvine, CA: Universal Publishers.

Benson, P. (2011). Teaching and Researching Autonomy in Language Learning. London: Routledge.

Berk, R. A. (2009). Multimedia Teaching with Video Clips: TV, Movies, YouTube, and $\mathrm{mtv} \mathrm{U}$ in the College Classroom. International Journal of Technology in Teaching \& Learning, 5, 1-21.

Davis, F. D., Bagozzi, R. P., \& Warshaw, P. R. (1989). User Acceptance of Computer Technology: A Comparison of Two Theoretical Models. Management Science, 35, 982-1003. https://doi.org/10.1287/mnsc.35.8.982

Farhady, H. (2013). Quantitative Methods. In The Encyclopedia of Applied Linguistics (pp. 4827-4836). Hoboken, NJ: Blackwell Publishing Ltd. https://doi.org/10.1002/9781405198431.wbeal0989

Ghasemi, B., Hashemi, M., \& Bardine, S. H. (2011). UTube and Language Learning. Procedia-Social and Behavioral Sciences, 28, 63-67. https://doi.org/10.1016/j.sbspro.2011.11.013

Hashim, H., \& Isa, I. S. M. (2012). Students' Anxiety Level towards Speaking in English: Malaysia Polytechnic Experience. In IEEE Symposium on Business, Engineering and Industrial Applications (pp. 595-599). Piscataway, NJ: IEEE. https://doi.org/10.1109/ISBEIA.2012.6422957

Hashim, H., Yunus, M. M., \& Embi, M. A. (2018). Factors Influencing Polytechnic English as Second Language (ESL) Learners' Attitude and Intention for Using Mobile Learning. Asian ESP Journal, 14, 195-208.

Littlewood, W. (1996). Autonomy: An Anatomy and a Framework. System, 24, 427-435. https://doi.org/10.1016/S0346-251X(96)00039-5

Mohd, N., \& Maat, S. (2013). An Investigation on ICT Application in Learning Mathematics among Engineering Technology Students. World Applied Sciences Journal, 21, 825-828.

Mohd Shah, P., \& Abdullah, H. I. (2014). Motivation and Attitudes towards Learning English among Undergraduates in National University of Malaysia (UKM). International Journal of English and Education, 3, 209-277.

Muniandy, B., \& Veloo, S. (2011). Managing and Utilizing Online Video Clips for Teaching English Language: Views of TESOL Pre-Service Teachers. International Journal of 
Social Science and Humanity, 13, 173-178.

Nawawi, M. H., Asmuni, A., \& Romiszowski, A. (2003). Distance Education Public Policy and Practice in the Higher Education: The Case of Malasya. Revista Brasileira de Aprendizagem Aberta e a Distância, 2, 1. https://doi.org/10.17143/rbaad.v2i0.129

Paulsen, P. (2001). New Era Trends and Technologies in Foreign Language Learning: An Annotated Bibliography. Interactive Multimedia Electronic Journal of Computer-Enhanced Learning, 4, 36-48. http://imej.wfu.edu/Articles/2001/1/05/index.asp

Sanaoui, R., \& Lapkin, S. (1992). A Case Study of an FSL Senior Secondary Course Integrating Computer Networking. The Canadian Modern Language Review, 43, 524-552. https://doi.org/10.3138/cmlr.48.3.525

Schmenk, B. (2005). Globalising Learner Autonomy. TESOL Quarterly, 9, 107-118. https://doi.org/10.2307/3588454

Sipalan, J. (2013). Report: Malaysian Youths Fourth Most Active Internet Users. http://www.themalaymailonline.com/malaysia/article/report-malaysian-youths-fourthmost-active-internet-users-globally

Sharif, M. S., Basri, H., \& Yunus, M. M. (2018). Youtube: Using Youtube as an Interactive Approach to Foster Confidence in Speaking among ESL Students (pp. 87-90).

Wang, L. (2005). The Advantages of Using Technology in Second Language Education: Technology Integration in Foreign Language Teaching Demonstrates the Shift from a Behavioral to a Constructivist Learning Approach. Technological Horizons in Education Journal, 32, 39-42.

Warschauer, M. (1996). Comparing Face-to-Face and Electronic Communication in the Second Language Classroom. CALICO Journal, 13, 7-26.

Yeboah, D. (2015). Challenges of Integrating Information and Communication Technology (ICT) in Basic Schools of Cape Coast Metropolis. Doctoral Dissertation, Cape Coast: University of Cape Coast.

Yunus, M. M., Hashim, H., Embi, M. A., \& Lubis, M. A. (2010). The Utilization of ICT in the Teaching and Learning of English: "Tell Me More". Procedia-Social and Behavioral Sciences, 9, 685-691. https://doi.org/10.1016/j.sbspro.2010.12.218

Yunus, M. M., Hashim, H. U., \& Hashim, H. (2019). Massive Open Online Courses: En Route to Communication Skills Acquisition. Arab World English Journal (AWEJ) Special Issue on CALL, No. 5, 98-109. https://doi.org/10.24093/awej/call5.8

Oxford, RMN (2004). Effects of Technology-Enhanced Language Learning on Second Language Composition of University-Level Intermediate Spanish Students. 